\title{
Pengaruh CAMEL Terhadap Financial Distress Pada Sektor Perbankan Indonesia Periode 2009-2013
}

\author{
Gina Sofiasani \\ Universitas Pendidikan Indonesia \\ Gsofiasani@yahoo.com \\ Budhi Pamungkas Gautama \\ Universitas Pendidikan Indonesia \\ budhipamungkas@upi.edu
}

\begin{abstract}
ABSTRAK
Penelitian ini dilatarbelakangi oleh kenaikan kemungkinan bank mengalami financial distress yang terjadi pada Sektor Perbankan Indonesia periode 2009-2013. Penelitian ini bertujuan untuk mengetahui 1) gambaran CAMEL yang terdiri dari unsur capital, management efficiency, earning dan liquidity, 2) gambaran financial distress, 3) Pengaruh capital, management efficiency, earning dan liquidity terhadap Financial Distress. Metode penelitian yang digunakan dalam penelitian ini adalah deskriptif dan verifikatif. Teknik analisis yang digunakan adalah analisis regresi multipel. Populasi dalam penelitian ini adalah Sektor Perbankan Indonesia yang berjumlah 120 bank. Sampel yang digunakan sebanyak sembilan bank pada Sektor Perbankan Indonesia periode 2009- 2013 dengan menggunakan teknik pengambilan sampel purposive sampling. Hasil penelitian ini, variabel capital yang diukur Capital Adequacy Ratio (CAR) dan liquidity yang diukur Loan to Deposit Ratio (LDR) tidak berpengaruh terhadap Financial Distress sedangkan management efficiency yang diukur Biaya Operasional Pendapatan Operasional (BOPO) dan earning yang diukur Return On Assets (ROA) berpengaruh terhadap financial distress.
\end{abstract}

Kata Kunci: Financial Distress, Capital, Management Efficiency, Earning dan Liquidity

Peranan utama sebuah bank yaitu menjalankan fungsi intermediasi keuangan dalam menghimpun dana dari pihak luar dan menyalurkannya kembali kepada pihak tertentu yang membutuhkan (Rose dan Hudgins, 2002:4). Fungsi intermediasi sebuah bank dapat berjalan baik dengan mengandalkan prinsip kepercayaan dari masyarakat. Oleh karena itu bank juga disebut sebagai agent of trust yaitu lembaga keuangan yang menjalankan kegiatan operasionalnya tergantung pada sumber dana dari masyarakat. Keberlangsungan usaha sebuah bank bergantung pada kepercayaan masyarakat. Merosotnya kepercayaan masyarakat pada suatu bank akan berdampak luas terhadap sistem perbankan sehingga dapat mengakibatkan krisis perbankan (Veitzhal, et al, 2012:97).

Selain sebagai agent of trust bank juga berperan sebagai agent of development yaitu lembaga keuangan yang memberikan kontribusi besar bagi pembangunan ekonomi sebuah negara. Pada level ekonomi makro bank sebagai alat untuk menetapkan kebijakan moneter sedangkan pada skala mikro bank merupakan sumber utama pembiayaan bagi para masyarakat serta menunjang kelancaran sistem pembayaran sehingga pergerakan roda perekonomian sebuah negara sangat bergantung pada dinamika dan kontribusi nyata dari sektor perbankan (Koch dan Scott, 2009:47).

Bank Indonesia sebagai bank sentral membagi bank kedalam beberapa jenis, yang kesemuanya itu merupakan gabungan dari beberapa klasifikasi bank yang telah dijelaskan di atas. Jenis bank tersebut diantaranya adalah Bank Persero, Bank Devisa, Bank Non Devisa, Bank Campuran, Bank Asing dan Bank Pembangunan Daerah yang berjumlah 120 bank. Setiap jenis bank tersebut tentu memiliki peran yang berbeda dalam menjalankan setiap kegiatan operasionalnya. Namun tetap semua bank yang masuk kedalam kategori jenis bank apapun, memiliki fungsi utama sebagai lembaga intermediasi dan berperan sangat penting bagi kestabilan roda perekonomian di suatu negara. Oleh karena itu setiap jenis bank tentu harus dapat menjaga kinerja nya agar tetap dalam kondisi yang sehat, salah satunya dengan mempertahankan pertumbuhan laba agar tetap tumbuh dengan baik. Gambar 1 berikut menggambarkan pertumbuhan laba pada seluruh Sektor Perbankan di Indonesia 


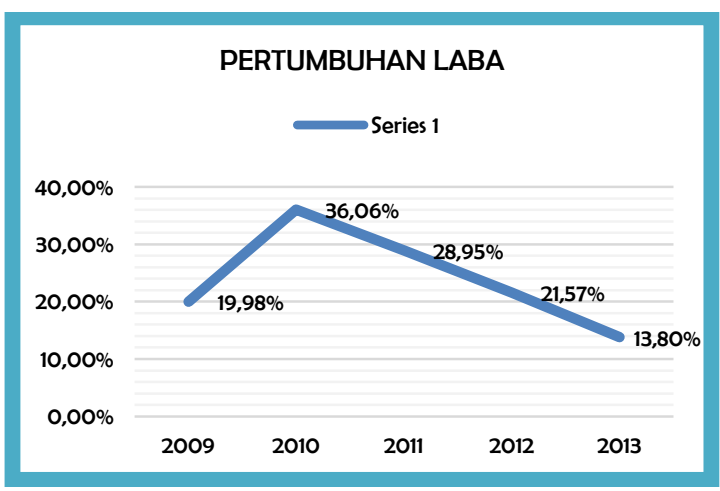

Sumber : Majalah Infobank, Edisi Juni 2014 (data diolah)

\section{GAMBAR 1 \\ PERTUMBUHAN LABA SEKTOR PERBANKAN INDONESIA PERIODE 2009-2013}

Dari Gambar 1.1 terlihat bahwa pertumbuhan laba Sektor Perbankan Indonesia selama periode 2009-2013 cenderung mengalami penurunan, kenaikan sebesar $16,08 \%$ terjadi pada tahun 2010 namun hingga tahun 2013 pertumbuhan laba terus mengalami penurunan yaitu sebesar $13,80 \%$ turun $7,70 \%$ dari tahun sebelumnya yang merupakan pertumbuhan paling rendah selama lima tahun terakhir.

Laba merupakan salah satu indikator untuk mengukur kondisi kesehatan sebuah bank, oleh karena itu perbankan Indonesia dituntut untuk terus dapat memepertahankan kekuatan labanya sehingga kinerja keuangan bank akan selalu berada pada kondisi yang sehat.
Karena jika bank tidak dapat menghasilkan laba dengan optimal, maka akan berpengaruh terhadap kemampuan bank dalam menjalankan kegiatan operasionalnya, menghambat keberlangsungan usaha sebuah bank sehingga akan menghadapi kesulitan dalam berkembang. Bahkan jika hal tersebut berlangsung terus menerus bank dapat terindikasi mengalami kondisi kesulitan keuangan atau yang disebut juga dengan financial distress.

Menurut Brigham dan Daves (2009: 868), financial distress merupakan kondisi dimana keuangan perusahaan dalam keadaan tidak sehat atau rawan kebangkrutan, dimulai ketika perusahaan tidak dapat memenuhi jadwal pembayaran atau ketika proyeksi arus kas yang mengindikasikan bahwa perusahaan tersebut tidak dapat memenuhi kewajibannya. Menurut John, Jens, dan Jan (2010:2), menyatakan bahwa perusahaan yang mengalami financial distress memiliki karakteristik diantaranya baru saja mengalami kerugian, dan nilai saham yang rendah.

Menurut Whitaker (1999), suatu perusahaan dapat dikatakan dalam kondisi financial distress atau kondisi bermasalah apabila perusahaan tersebut mengalami laba bersih (net income) negatif selama beberapa tahun, oleh karena itu penulis menggunakan net income sebagai indikator financial distress. Tabel 1 berikut adalah daftar bank pada Sektor Perbankan Indonesia periode 2009-2013 yang terindikasi mengalami financial distress.

TABEL 1

KONDISI FINANCIAL DISTRESS PADA SEKTOR PERBANKAN INDONESIA PERIODE 2009-2013 Net Income (Dalam Jutaan Rupiah)

\begin{tabular}{|l|r|r|r|r|r|}
\hline \multicolumn{1}{|c|}{ Nama Bank } & \multicolumn{1}{c|}{$\mathbf{2 0 0 9}$} & \multicolumn{1}{c|}{$\mathbf{2 0 1 0}$} & \multicolumn{1}{c|}{$\mathbf{2 0 1 1}$} & \multicolumn{1}{c|}{$\mathbf{2 0 1 2}$} & \multicolumn{1}{c|}{$\mathbf{2 0 1 3}$} \\
\hline Anglomas International & 2.255 & -2.501 & -1.301 & -1.580 & -2.071 \\
\hline Andara & -22.419 & -21.923 & -18.170 & -3.202 & -40.311 \\
\hline ICB Bumiputera & 5.043 & 12.169 & -81.056 & -173.946 & 1.119 \\
\hline Mutiara & 265.483 & 217.963 & 260.445 & 145.338 & -1.136 .045 \\
\hline Nasional Nobu & 1.821 & 1.834 & 1.915 & 3.706 & -51.669 \\
\hline Yudha Bakti & 11.854 & 28.905 & 23.257 & 18.780 & -2.278 \\
\hline Pundi & -134.870 & 90.161 & -117.991 & 14.255 & 63.732 \\
\hline Bank Of America & 739 & -3.252 & 18.117 & -19.025 & 12.521 \\
\hline Bank Of Scotland & -21.990 & -44.921 & 3.350 & -76 & 64.859 \\
\hline Rata-Rata & 11.990 & 30.937 & 9.840 & -1.750 & -121.127 \\
\hline
\end{tabular}

Sumber : Annual Report (Data Diolah)

Berdasarkan Tabel 1 secara rata-rata net income cenderung mengalami penurunan selama dua tahun terakhir yaitu pada 2012 sebesar Rp.-1.750 juta dan net income paling rendah terjadi pada 2013 yaitu sebesar Rp.-121.127 juta. Hal tersebut tentu menjadi sebuah permasalahan yang harus segera ditangani oleh sebuah lembaga perbankan yang keberadaan dan perannya crucial bagi stabilitas roda perekonomian sebuah negara. 
Bank yang diduga mengalami financial distress menandakan bank berada dalam kondisi yang kurang sehat, sehingga menyebabkan fungsi intermediasi akan terganggu, maka sumber pembiayaan bagi masyarakat untuk kegiatan konsumsi dan investasi dalam perekonomian akan terbatas, sehingga lalu lintas sistem pembayaran menjadi tidak lancar dan tidak efisien. Ketidakpastian tingkat kesehatan suatu bank juga dapat mengakibatkan penarikan dana secara besarbesaran, hal tersebut terjadi dikarenakan kepercayaan masyarakat terhadap industri perbankan yang rendah, sehingga akan berpengaruh pada kelangsungan hidup sebuah bank dan berkontribusi pada roda perekonomian yang akan melambat (Veitzhal, et al, 2012:97).

Deteksi dini untuk mengetahui sebuah bank yang terindikasi mengalami financial distress atau dalam kondisi yang sehat merupakan hal yang harus selalu diperhatikan oleh para regulator bank. Tentunya dengan melakukan deteksi sedini mungkin, maka memungkinkan bank akan terhindar dari berbagai permasalahan dapat diminimalisir. (Olivier Brossard et al. 2007:1).

Bank Indonesia dalam mendeteksi kondisi kesehatan bank pada dasarnya menggunakan pendekatan kualitatif atas berbagai aspek yang berpengaruh terhadap kondisi kondisi suatu bank. Metode atau cara penilaian tingkat kesehatan bank tersebut dikenal dengan metode CAMEL, yang merupakan aspek yang banyak berpengaruh terhadap kondisi keuangan serta kesehatan sebuah bank (Veitzhal, et al, 2012:465).

Mishra dan Parvesh (2013:53), melakukan penelitian dengan mengevaluasi kinerja kesehatan keuangan State Bank Group India menggunakan pendekatan CAMEL dan menyimpulkan bahwa CAMEL dapat dijadikan pendekatan yang efektif untuk menilai kesehatan sebuah bank.

CAMEL mengevaluasi sebuah lembaga keuangan dengan memperhatikan beberapa unsur atau dimensi yang dapat berpengaruh terhadap kinerja sebuah bank yang terdiri dari Capital, Asset Quality, Management Efficiency, Earning dan Liquidity (Ferrouchi, 2014:622). Unsur-unsur tersebut diproksikan menjadi beberapa indikator yaitu Capital Adequacy Ratio (CAR), Non Performing Loan (NPL), Return on Equity (ROE), Return on Assets (ROA), Net Interest Margin (NIM), Biaya Operasional terhadap Pendapatan Operasional (BOPO) dan Loan to Deposit Ratio (LDR) (Surat Edaran Bank Indonesia Nomor 3/30/DPNP tanggal 14 Desember 2001).

Dalam penelitian ini unsur CAMEL yang digunakan hanya unsur capital, management efficiency, earning dan liquidity. Sedangkan unsur assets quality diduga bukan menjadi penyebab Sektor Perbankan Indonesia mengalami dugaan financial distress. Berdasarkan uraian tersebut, maka penulis merasa perlu melakukan penelitian dengan judul "Pengaruh CAMEL Terhadap Financial Distress Pada Sektor Perbankan Indonesia Periode 2009-2013. Adapun tujuan dari penelitian ini adalah untuk memperoleh hasil temuan mengenai: 1) Gambaran kondisi Capital, Management Efficiency, Earning dan Liquidity pada Sektor Perbankan Indonesia periode 2009-2013. 2) Gambaran kondisi Financial Distress pada Sektor Perbankan Indonesia periode 2009-2013. 3) Gambaran pengaruh Capital, Management Efficiency, Earning dan Liquidity terhadap Financial Distress pada Sektor Perbankan Indonesia periode 2009-2013.

\section{KAJIAN PUSTAKA}

Bank Indonesia dalam menilai tingkat kesehatan suatu bank pada dasarnya mengacu pada pendekatan kualitatif atas berbagai aspek yang berpengaruh terhadap kondisi suatu bank. Metode atau cara penilaian tingkat kesehatan bank tersebut kemudian dikenal dengan metode CAMEL yang merupakan aspek yang berpengaruh terhadap kondisi keuangan bank, yang mempengaruhi pula kesehatan bank. Setelah dilakukan pengukuran dengan cara CAMEL, dilanjutkan dengan penilaian tingkat kepatuhan bank pada beberapa ketentuan khusus. Metode CAMEL berisikan langkah-langkah yang dinilai dengan menghitung besarnya masingmasing rasio pada komponen-komponen (Veitzhal et al, 2012:465).

Menurut Almilia dan Winny (2005:133), rasio CAMEL menggambarkan suatu hubungan atau perbandingan antara suatu jumlah tertentu dengan jumlah yang lain. Dengan analisis rasio tersebut dapat diperoleh gambaran baik buruknya keadaan atau posisi keuangan suatu bank. Menurut Ridwan Nurazi dan Michael Evans (2005:2), rasio CAMEL merupakan rasio yang digunakan untuk mengevaluasi kondisi keuangan sebuah bank serta digunakan sebagai alat untuk memprediksi permasalahan keuangan sebuah bank.

Mishra dan Aspal (2013:53), mengevaluasi kinerja kesehatan keuangan State Bank Group India menggunakan pendekatan CAMEL dan menyimpulkan bahwa CAMEL dapat dijadikan pendekatan yang efektif untuk menilai kesehatan sebuah bank. Sedangkan menurut Rahman dan Mazni (2014:451), menyatakan bahwa CAMEL dapat dijadikan alat pengukuran yang baik untuk memprediksi financial distress bank Islam yang ada Malaysia dengan memperkirakan kinerja dan efisiensi sebuah bank di masa yang akan datang.

Sedangkan menurut CA. Ruchi Gupta (2014:95), CAMEL merupakan rasio yang dapat digunakan untuk mengevaluasi kesehatan sebuah bank dengan bantuan kriteria Capital, Asset Quality, Management Efficiency, Earning and Liquidity". Dari beberapa uraian di atas Rasio CAMEL adalah alat yang digunakan untuk mengevaluasi kinerja 
perusahaan perbankan dan dapat pula digunakan untuk memprediksi kondisi bermasalah atau yang disebut dengan financial distress suatu perusahaan perbankan.

Sistem peringatan awal untuk mengantisipasi adanya financial distress penting untuk dikembangkan karena akan sangat bermanfaat bagi pihak internal dan eksternal perusahaan. Karena dengan adanya peringatan ini, maka pihak internal perusahaan akan lebih cepat untuk mengambil tindakan, yang mana akan dapat memperbaiki kondisi keuangan perusahaan sebelum mengalami kebangkrutan. Pihak eksternal pun dalam hal ini akan dapat terbantu dalam proses pengambilan keputusan apakah akan berinvestasi atau tidak pada perusahaan tersebut (Arwinda dan Lely, 2014:96).

Financial distress merupakan kondisi dimana keuangan perusahaan dalam keadaan tidak sehat atau krisis. Menurut Brigham dan Daves (2009:868), financial distress dimulai ketika perusahaan tidak dapat memenuhi jadwal pembayaran atau ketika proyeksi arus kas mengindikasikan bahwa perusahaan tersebut akan segera tidak dapat memenuhi kewajibannya.

Menurut John, Jens, dan Jan (2010:2), menyatakan bahwa perusahaan yang mengalami financial distress memiliki karakteristik diantaranya baru saja mengalami kerugian, dan nilai saham yang rendah. Platt dan Platt (2006:144), menyatakan perusahaan dapat dikatakan sedang mengalami financial distress dapat bersumber dari earning, yaitu apabila selama dua tahun perusahaan tersebut memiliki EBITDA (Earning Before Interest Tax Deperesiation dan Amortization), EBIT (Earning Before Interest and Tax) dan Net Income yang negatif. Menurut Whitaker (1999), suatu perusahaan dapat dikatakan dalam kondisi financial distress atau kondisi bermasalah apabila perusahaan tersebut mengalami laba bersih (net income) negatif selama beberapa tahun, oleh karena itu penulis menggunakan net income sebagai indikator financial distress.

Oleh karena itu kesehatan perbankan dengan menggunakan model CAMEL diharapkan dapat menjadi sistem deteksi dini kondisi financial distress sebuah bank. Indikator CAMEL yang digunakan dalam penelitian ini diantaranya adalah capital, management efficiency, earning dan liquidity.

Unsur yang pertama yaitu capital. Modal merupakan faktor yang penting bagi bank dalam rangka pengembangan usaha dan menampung kerugian serta mencerminkan kesehatan bank yang bertujuan untuk menjaga kepercayaan masyarakat pada industri perbankan, melindungi dana masyarakat pada bank bersangkutan dan untuk memenuhi standar yang ditentukan. Faktor permodalan sangat penting dalam menjalankan kegiatan operasional bank dan menunjang segala kebutuhannya, dengan kualitas pihak manajemen dalam pengelolaan kegiatan perbankan mendapatkan laba yang diharapkan (Pasaribu dan Rosa, 2011:117).

Pada dasarnya bank akan selalu berusaha untuk meningkatkan jumlah dana sendiri, selain untuk memenuhi capital adequacy juga untuk memperkuat ekspansi dan bersaing. Kemampuan setiap bank untuk meningkatkan modal akan tercermin dari capital adequacy bank tersebut. Hal ini merupakan salah satu tingkat kemampuan bank untuk menghindari kondisi financial distress sehingga dapat meningkatkan kesehatan suatu bank, yang akhirnya akan meningkatkan kepercayaan masyarakat terhadap bank (Veithzal,et al., 2012:183).

Pada umumnya rasio yang digunakan untuk mengukur kecukupan modal bank adalah dengan menggunakan Capital Adequacy Ratio (CAR). Menurut CA. Ruchi Gupta (2014:95), Modal merupakan aspek yang dapat mempengaruhi persepsi deposan mengenai sebuah bank. Oleh karena itu manajemen bank hendaknya dapat menjaga capital adequacy dalam level yang aman. Capital adequacy merupakan aspek yang sangat penting untuk melindungi kepercayaan pemegang saham dan menghindari bank dari ancaman kesulitan keuangan (financial distress)

David G and Hanno Stremmel (2014:18), mengatakan bahwa capital adequacy memiliki pengaruh yang signifikan terhadap kondisi financial distress, penurunan total modal terhadap aset mengindikasikan bank mengalami kemungkinan financial distress.

Bank dengan modal yang tinggi dianggap relatif lebih aman dibandingkan dengan bank modal yang rendah, hal ini disebabkan bank dengan modal yang tinggi biasanya memiliki kebutuhan yang lebih rendah dari pada pendanaan eksternal. Akan tetapi keberhasilan suatu bank bukan terletak pada jumlah modal yang dimilikinya, tetapi lebih didasarkan pada bagaimana bank tersebut mempergunakan modal itu untuk menarik sebanyak mungkin dana/simpanan masyarakat yang kemudian disalurkannya kembali kepada masyarakat yang membutuhkannya sehingga membentuk pendapatan bagi bank tersebut (Frianto, 2012:28).

Oleh karena itu pihak manajemen bank sangat perlu untuk memperhatikan besanya CAR yang ideal, jangan terlalu tinggi karena akan meningkatkan dana yang idle dan juga jangan terlalu rendah karena akan dapat menyebabkan permasalahan bagi bank antara lain bank akan kehilangan kepercayaan dari masyarakat, sehingga dana pihak ketiga bank sangat dimungkinkan akan mengalami penurunan yang drastis (Sukarno dan Syaichu 2006:53).

Unsur kedua yang mempengaruhi kondisi financial distress adalah management efficiency. Bank yang dalam kegiatan usahanya tidak efisien akan mengakibatkan ketidakmampuan bersaing 
dalam mengerahkan dana masyarakat maupun dalam menyalurkan dana tersebut kepada masyarakat yang membutuhkan sebagai modal usaha. Dengan adanya efisiensi pada lembaga perbankan terutama efisiensi biaya maka akan diperoleh tingkat keuntungan yang lebih optimal, penambahan jumlah dana yang disalurkan, peningkatan pelayanan bank kepada nasabah, keamanan dan kesehatan perbankan yang meningkat sehingga terhindar dari ancaman financial distress (Kuncoro dan Suhardjono, 2002:569).

Indikator dalam unsur management efficiency yang digunakan adalah BOPO. Frianto (2012:72), berpendapat bahwa BOPO digunakan untuk mengukur kemampuan manajemen bank dalam mengendalikan biaya operasional terhadap pendapatan operasional. Semakin kecil BOPO berarti semakin kecil efisien biaya operasional yang dikeluarkan bank yang bersangkutan sehingga kemungkinan suatu bank dalam kondisi financial distress semakin kecil.

Faktor selanjutnya yang mempengaruhi financial distress adalah earning. Earning untuk memastikan efisiensi dan kualitas pendapatan secara benar dan akurat. Kelemahan dari sisi earning merupakan indikator terhadap potensi bank mengalami financial distress. Penilaian earning merupakan penilaian terhadap kondisi dan kemampuan bank menghasilkan pendapatan untuk mendukung kegiatan operasionalnya dan permodalan, karena dengan berjalannya kegiatan operasional dengan baik dan permodalan yang semakin kuat dapat berpengaruh pada keberlangsungan usaha sebuah bank (Veitzhal, et al, 2012:480).

Menurut CA. Ruchi Gupta (2014:98), satusatunya indikator terbaik dalam mengukur earning adalah menggunakan ROA. Dalam dunia perbankan Dendawijaya (2009:120), mengungkapkan bahwa ROA digunakan untuk mengukur kemampuan manajemen bank dalam memperoleh keuntungan atau laba secara keseluruhan. Semakin besar ROA suatu bank, semakin besar pula tingkat keuntungan yang dicapai oleh bank tersebut dan semakin baik pula posisi bank tersebut dari segi penggunaan aset.

Faktor terakhir yang mempengaruhi financial distress adalah liquidity. Menurut Frianto (2012:113), likuiditas merupakan kemampuan bank untuk memenuhi kewajiban jangka pendek. Suatu bank dianggap liquid apabila bank tersebut mempunyai kesanggupan untuk membayar penarikan giro, tabungan, deposito berjangka, pinjaman bank yang segera jatuh tempo, pemenuhan perminataan kredit tanpa adanya suatu penundaan (kredit yang direalisasi).

Risiko kekurangan likuiditas terjadi karena adanya rush penarikan dana secara serentak yang akan mengakibatkan bank mengalami kesulitan keuangan (financial distress) bahkan ancaman kebangkrutan. Hal itu disebabkan oleh kesalahan dalam manajemen aset yaitu melakukan investasi yang beresiko tinggi untuk mendapatkan pengembalian yang tinggi serta kesalahan dalam manajemen modal yaitu modal yang dimiliki bank terlalu rendah karena lebih mementingkan keuntungan pemilik bank (Silvanita, 2009:29)

Salah satu cara dalam mengukur likuiditas bank yaitu dapat diukur dengan Loan to Deposit (LDR). LDR merupakan rasio untuk mengukur komposisi jumlah kredit yang diberikan dibandingkan dengan jumlah dana masyarakat dan modal sendiri yang digunakan. Semakin rendah nilai LDR semakin likuid karena tidak semua dana pihak ketiga dialokasikan kedalam bentuk kredit sehingga masih memiliki cadangan kas sebagai sumber likuiditas (Kasmir, 2012:319).

Veithzal Rivai, Andria dan Ferry (2007:724), yang berpendapat bahwa semakin tinggi rasio ini, maka semakin tinggi dana yang disalurkan ke dana pihak ketiga, sehingga LDR yang meningkat dapat meningkatkan kemampuan bank menghasilkan keuntungan. Akan tetapi, semakin tinggi rasionya mengindikasikan rendahnya kemampuan likuiditas bank, hal ini karena jumlah dana yang diperlukan untuk membiayai kredit menjadi semakin besar.

Sehingga dapat dikatakan bahwa perolehan dana pihak ketiga yang dilakukan untuk penyaluran kredit yang tinggi, tidak selalu mengurangi tingkat kesehatan bank karena tidak memiliki cadangan kas yang cukup untuk memenuhi kebutuhan dana. Akan tetapi bank akan tetap dalam kondisi yang sehat ketika bank memiliki aktiva yang cukup likuid bilamana harus mencairkan untuk menutupi kebutuhan dana (Anam, 2013:3).

Berdasarkan landasan teori dan penelitian terdahulu tersebut, mengenai berbagai pengaruh antara variabel independen yang terdiri dari Capital, Management Efficiency, Earning dan Liquidity dan variabel dependen yaitu financial distress, maka dapat digambarkan paradigma penelitian dalam Gambar 2 


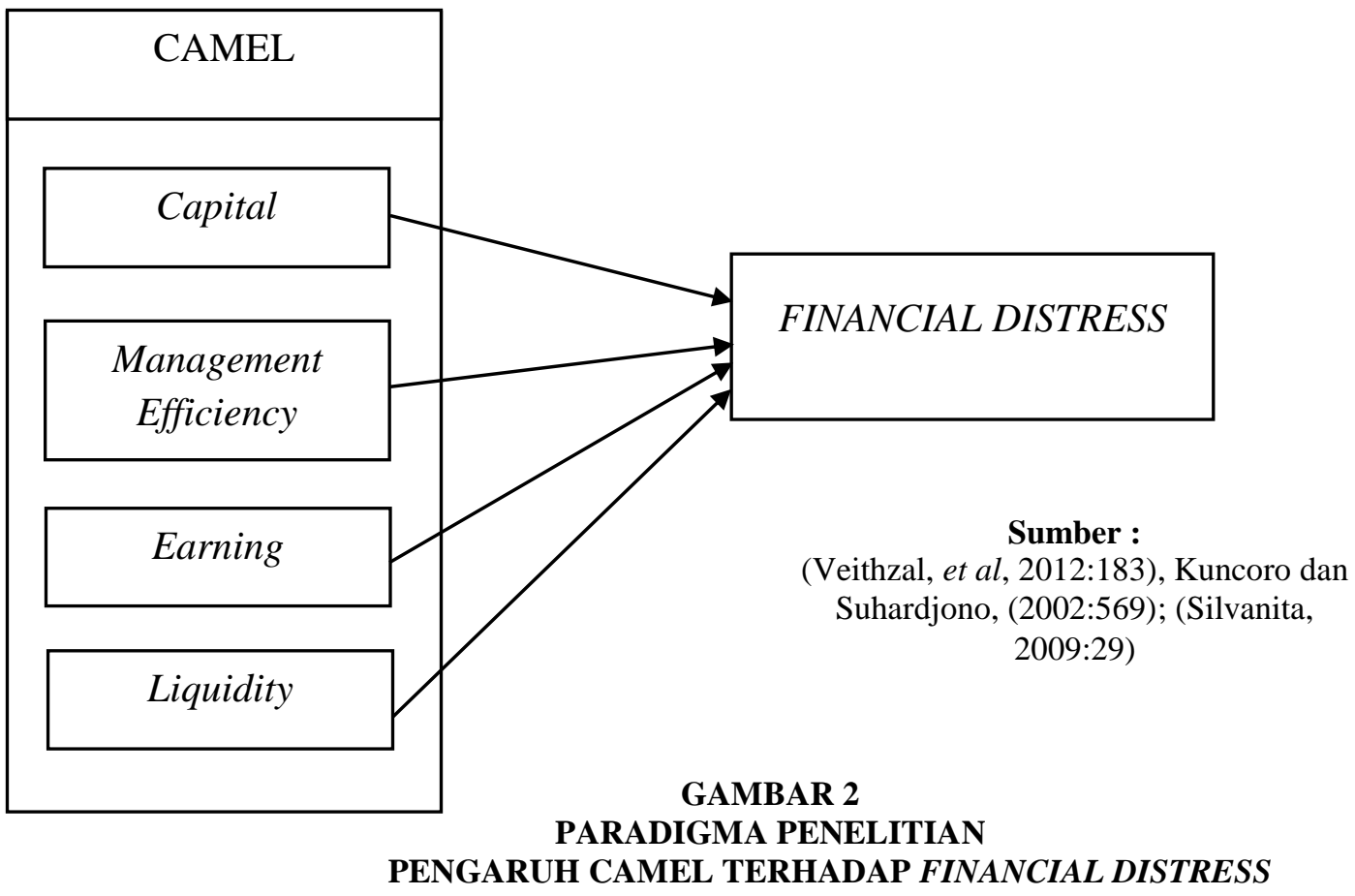

Berdasarkan gambar paradigma penelitian di atas maka hipotesis dari penelitian ini adalah sebagai berikut :

1. Capital berpengaruh terhadap financial distress

2. Management Efficiency berpengaruh terhadap financial distress

3. Earning berpengaruh terhadap financial distress

4. Liquidity berpengaruh terhadap financial distress

\section{METODE PENELITIAN}

Penelitian ini menganalisis laporan keuangan menggunakan rasio CAMEL pada Sektor Perbankan di Indonesia serta pengaruhnya terhadap kondisi financial distress. Adapun yang menjadi variabel bebas (independent variable) adalah Rasio CAMEL yang terdiri dari Capital yang diukur dengan Capital Adequacy Ratio (CAR), Management Efficiency yang diukur dengan Biaya Operasional Pendapatan Operasional (BOPO), Earning yang diukur dengan Rerurn on Assets (ROA) dan Liquidity yang diukur dengan Loan to Deposit Ratio (LDR). Variabel dependent adalah Financial Distress yang diukur dengan net income (Y).
Populasi dalam penelitian ini adalah 120 Laporan Keuangan bank pada Sektor Perbankan Indonesia periode 2009-2013. Teknik penarikan sampel yang digunakan yaitu teknik purposive sampling dengan kriteria sampel adalah: Pertama, Perusahaan Sektor Perbankan Indonesia yang terdaftar di Direktori Perbankan Indonesia periode 2009-2013. Kedua, Bank pada Sektor Perbankan Indonesia yang terindikasi mengalami financial distress yang memiliki net income negatif periode 2009-2013. Ketiga, Menyajikan laporan keuangan lengkap selama periode 2009-2013. Dengan kriteria tersebut dapat diambil sampel sebanyak 9 laporan keuangan bank pada Sektor Perbankan Indonesia.

Pengujian hipotesis dalam penelitian ini menggunakan analisis regresi multipel yang bertujuan menunjukkan pengaruh beberapa variabel independen terhadap variabel dependen. Penelitian ini menggunakan 4 variabel independen, yaitu capital, management efficiency, earning dan liquidity dengan variabel dependen financial distress. Persamaan regresi kemudian menghasilkan konstanta dan koefisien regresi bagi masing-masing variabel bebas. Adapun model dasar dari regresi linier berganda dari penelitian ini dapat dirumuskan sebagai berikut :

Dimana:

$$
Y=a+b_{1} X_{1}+b_{2} X_{2}+b_{3} X_{3}+b_{4} X_{4}+e
$$

$\mathrm{Y} \quad$ : variabel dependen/terikat, financial distress

a : konstanta (harga $\mathrm{Y}$ untuk $\mathrm{X}_{1}=0, \mathrm{X}_{2}=0, \mathrm{X}_{3}=0, \mathrm{X}_{4}=0$

$\mathrm{b}_{1} \quad$ : angka arah (koefisien regresi) dari prediktor $\mathrm{X}_{1}$

$\mathrm{b}_{2} \quad$ : angka arah (koefisien regresi) dari prediktor $\mathrm{X}_{2}$

$b_{3} \quad$ : angka arah (koefisien regresi) dari prediktor $X_{3}$ 
$\mathrm{b}_{4} \quad$ : angka arah (koefisien regresi) dari prediktor $\mathrm{X}_{4}$

$\mathrm{X}_{1} \quad$ : Variabel independen 1 (prediktor 1), Capital (CAR)

$\mathrm{X}_{2} \quad$ : Variabel independen 2 (prediktor 2), Management Efficiency (BOPO)

$\mathrm{X}_{3} \quad$ : Variabel independen 3 (prediktor 3), Earning (ROA)

$\mathrm{X}_{4} \quad$ : Variabel independen 4 (prediktor 4), Liquidity (LDR)

\section{HASIL PENELITIAN DAN PEMBAHASAN}

\section{Gambaran Objek Penelitian}

Objek penelitian yang digunakan dalam penelitian ini adalah sembilan bank pada Sektor Perbankan Indonesia. khususnya jenis Bank Devisa, Bank Non Devisa dan Bank Asing yang terindikasi mengalami kondisi financial distress karena terdapat sembilan bank yang mengalami net income negatif pada periode tahun 2009-2013. Terdapat lima Bank Non Devisa yaitu Bank Anglomas Internasional, Bank Andara, Bank Nasional Nobu, Bank Yudha

Bakti dan Bank Pundi. Jenis Bank Devisa terdapat dua bank yaitu Bank ICB Bumiputera \& Bank Mutiara. Sedangkan untuk jenis Bank Asing terdiri dari Bank of America dan The Royal Bank of Scotland.

\section{Analisis Regresi Linear Multipel}

Pengujian statistika digunakan untuk menguji keberartian koefisien regresi pengaruh masing-masing variabel Uji dilakukan dengan menggunakan Software SPSS v 21 for Windows. Hasil pengujian model regresi secara parsial diperoleh sebagai berikut:

TABEL 2

HASIL UJI KEBERARTIAN KOEFISIEN REGRESI (UJI T)

\begin{tabular}{|c|c|c|c|c|c|c|}
\hline \multirow{2}{*}{\multicolumn{2}{|c|}{ Model }} & \multicolumn{2}{|c|}{ Unstandardized Coefficients } & \multirow{2}{*}{$\begin{array}{c}\text { Standardized } \\
\text { Coefficients } \\
\text { Beta }\end{array}$} & \multirow[t]{2}{*}{$\mathrm{T}$} & \multirow[t]{2}{*}{ Sig. } \\
\hline & & $\mathrm{B}$ & Std. Error & & & \\
\hline \multirow{5}{*}{1} & (Constant) & $2.262 .853 .330,204$ & $33.863 .129 .797,185$ & & ,067 & ,947 \\
\hline & CAR & $-2.546 .925,160$ & $48.725 .749,917$ &,- 007 &,- 052 & ,959 \\
\hline & BOPO & 1.067.697.744,985 & $297.670 .477,377$ & ,483 & 3,587 &, 001 \\
\hline & ROA & $-22.546 .482 .335,556$ & $5.120 .065 .878,905$ &,- 604 & $-4,404$ &, 000 \\
\hline & LDR & $-245.651 .250,021$ & $146.820 .141,556$ &,- 223 & $-1,673$ & 102 \\
\hline
\end{tabular}

a. Dependent Variable: FINANCIAL_DISTRESS

Berdasarkan hasil perhitungan analisis regresi linear multipel pada Tabel 2 dapat diketahui bahwa nilai konstanta $\left(a_{0}\right)$ adalah sebesar 2,263. Untuk nilai koefisien Capital $\left(\mathrm{X}_{1}\right)$ sebesar $\quad-2.546 .925 .160$ dengan tingkat signifikansi 0,959. Nilai koefisien Management Efficieciency $\left(\mathrm{X}_{2}\right)$ sebesar 1.067.697.744,985 dengan tingkat signifikansi 0,001. Nilai koefisien Earning $\left(\mathrm{X}_{3}\right)$ sebesar $-22.546 .482 .335,556$ dengan tingkat signifikansi 0,000. Nilai koefisien Liquidity (X4) sebesar -245.651.250,021 dengan tingkat signifikansi 0,102 .

\section{Kondisi Capital Pada Sektor Perbankan Indonesia}

Kondisi capital yang diukur dengan menggunakan CAR Sektor Perbankan Indonesia periode 2009-2013 mengalami penurunan, namun nilai CAR yang diperoleh tinggi jauh di atas batas minimum yang ditentukan BI yaitu $8 \%$. Rata-rata nilai CAR tertinggi terjadi pada tahun 2009 yaitu sebesar 324,15\%. Nilai CAR yang tinggi menandakan bank memiliki cadangan modal untuk menyerap berbagai kerugian atas resiko aktiva yang terjadi tidak terduga. Akan tetapi cadangan modal yang terlalu tinggi akan menjadi idle fund (dana yang menganggur) dan meningkatkan biaya yang akan ditanggung sehingga tidak akan memberikan keuntungan yang optimal bagi bank.

Sedangkan rata-rata nilai CAR terendah terjadi pada tahun 2012 yaitu sebesar $43,16 \%$. Nilai CAR yang rendah menandakan bank tidak memiliki cadangan modal yang cukup untuk menutupi kerugian atas aktiva bank yang mengandung resiko. Nilai CAR yang rendah juga akan mengurangi kepercayaan deposan sehingga akan meningkatkan kemungkinan bank mengalami kondisi keuangan yang tidak sehat.

\section{Kondisi Management Efficiency Pada Sektor Perbankan Indonesia}

Kondisi management efficiency yang diukur dengan menggunakan Biaya Operasional terhadap Pendapatan Operasional (BOPO) Sektor Perbankan Indonesia periode 2009-2013 mengalami kenaikan, namun nilai BOPO yang diperoleh sebagian besar masih berada di atas 
batas minimum standar BI yaitu $85 \%$. Rata-rata nilai BOPO tertinggi terjadi pada tahun 2009 sebesar 109,69\%. Nilai BOPO yang tinggi menandakan penggunaan sumber daya yang dikelola bank kurang efisien sehingga meningkatkan biaya operasional yang tinggi dan kegiatan operasional tidak dapat berjalan dengan semestinya yang akan menghambat perolehan pendapatan bank yang optimal.

Sedangkan rata-rata nilai $\mathrm{BOPO}$ terendah terjadi pada tahun 2012 yaitu sebesar $109,09 \%$. Nilai BOPO yang rendah menandakan bank memiliki kemampuan dalam menggunakan sumber daya secara efisien sehingga dapat mengendalikan biaya operasional yang tinggi mengakibatkan kegiatan operasional dapat berjalan dengan baik dan mendorong bank memperoleh pendapatan yang optimal.

\section{Kondisi Earning Pada Sektor Perbankan Indonesia}

Earning diukur dengan menggunakan ROA pada Sektor Perbankan Indonesia periode 2009-2013 mengalami penurunan, namun nilai ROA yang diperoleh sebagian besar masih berada di bawah batas minimum standar BI. Rata-rata nilai ROA tertinggi terjadi pada tahun 2012 sebesar $0,28 \%$. Nilai ROA yang tinggi mengindikasikan bank memiliki kemampuan untuk mengelola aset secara efektif dan efisien sehingga memberikan pengembalian sesuai yang diharapkan bank dengan perolehan keuntungan yang optimal.

Sedangkan rata-rata nilai ROA terendah terjadi pada tahun 2010 sebesar $-1,45 \%$. Nilai ROA yang rendah mengindikasikan rendahnya kemampuan bank menggunakan aset dengan efisien sehingga memberikan pengembalian yang minimum yang mengakibatkan keuntungan yang diperoleh bank tidak optimal.

\section{Kondisi Earning Pada Sektor Perbankan Indonesia}

Liquidity diukur dengan

menggunakan LDR pada Sektor Perbankan Indonesia periode 2009-2013 mengalami kenaikan, namun nilai LDR yang diperoleh sebagian besar masih berada di atas batas minimum standar BI yaitu $110 \%$. Rata-rata nilai LDR tertinggi terjadi pada tahun 2013 sebesar $148,39 \%$. Nilai LDR yang tinggi menandakan kemampuan likuiditas bank yang rendah karena sebagian besar dana yang dihimpun disalurkan dalam bentuk kredit, yang akan menyebabkan rendahnya cadangan aset likuid yang dimiliki bank akan tetapi kredit yang diberikan bank dapat menjadi sumber likuiditas bank dengan asumsi bank tidak mengalami resiko gagal bayar.
Sedangkan rata-rata nilai LDR terendah terjadi pada tahun 2009 yaitu sebesar $71,50 \%$. Nilai LDR yang rendah menandakan tingkat likuiditas bank yang tinggi karena tidak semua dana yang dihimpun bank disalurkan kedalam bentuk kredit sehingga cadangan aset likuid yang dimiliki bank tinggi bilamana bank memiliki kebutuhan dana yang mendesak. Akan tetapi cadangan yang terlalu tinggi mengindikasikan bank terlalu banyak menyimpan dana yang menganggur sehingga akan menambah beban bunga bagi bank dan kemungkinan bank memiliki pendapatan yang optimal akan semakin rendah.

\section{Kondisi Financial Distress Pada Sektor Perbankan Indonesia}

Kondisi financial distress yang diukur dengan net income pada Sektor Perbankan Indonesia dapat terlihat bahwa terdapat sembilan bank yang terindikasi mengalami financial distress periode 2009-2013 karena memiliki net income yang negatif. Secara rata-rata kondisi net income tertinggi terjadi pada 2010 yang tercatat sebesar Rp.30.937 juta. Net income yang tinggi mengindikasikan bahwa kemungkinan bank mengalami financial distress rendah karena bank tidak mengalami kerugian dan keberlangsungan usaha dapat berjalan dengan semestinya sehingga dapat mencetak laba yang tinggi dan kinerja keuangan bank tersebut dalam kategori yang sehat.

Sedangkan rata-rata kondisi net income terendah terjadi pada tahun 2013 yang tercatat sebesar Rp.-121.127 juta. Net income yang rendah mengindikasikan bahwa kemungkinan bank mengalami financial distress akan terjadi, karena mengalami kerugian yang mengakibatkan keberlangsungan usaha dapat terhambat dan kinerja keuangan bank dalam keadaan yang rawan akan kebangkrutan jika tidak dilakukan antisipasi yang tepat.

\section{Pengaruh Capital terhadap Financial Distress Sektor Perbankan Indonesia}

Hasil penelitian empiris diperoleh keterangan bahwa capital yang diukur dengan CAR tidak berpengaruh terhadap financial distress hal tersebut dibuktikan pada hasil statistik yang menyatakan estimasi regresi variabel capital yang diukur dengan CAR diperoleh nilai signifikansi dari $t_{\text {hitung }}$ adalah 0,959 yang artinya nilai tersebut lebih besar dari taraf nyata $5 \%$.

Dari hasil penelitian tersebut dapat dikatakan bahwa capital tidak selalu berpengaruh pada kondisi financial distress, hal tersebut berbeda dengan penelitian yang dilakukan oleh David G and Hanno Stremmel (2014:18). 
Hal berbeda terjadi dalam penelitian ini yang menunjukkan bahwa nilai capital Sektor Perbankan Indonesia periode 2009-2013 cenderung mengalami kenaikan yang terlalu tinggi namun tidak diikuti oleh penurunan kondisi financial distress karena terjadi penurunan net income. Hal ini mengindikasikan bahwa bank tidak mengalokasikan dana yang dihimpunnya dalam bentuk kredit dan terlalu banyak mencadangkan modalnya dan mengakibatkan banyak dana yang menganggur sehingga dana yang seharusnya dapat dialokasikan kedalam kegiatan usaha perbankan yang lebih produktif tidak memberikan kesempatan bank untuk memperoleh keuntungan yang lebih besar. Teori ini sesuai dengan yang dikemukakan oleh (Frianto, 2012:28) dan (Sukarno dan Syaichu, 2006:53).

\section{Pengaruh Management Efficiency terhadap Financial Distress Sektor Perbankan Indonesia}

Hasil penelitian empiris diperoleh keterangan bahwa management efficiency yang diukur dengan BOPO memiiliki pengaruh signifikan terhadap financial distress, hal tersebut dibuktikan pada hasil statistik yang menyatakan estimasi regresi variabel management efficiency yang diukur dengan BOPO diperoleh nilai signifikansi dari thitung adalah 0,001 yang artinya nilai tersebut lebih kecil dari taraf nyata $5 \%$.

Kondisi management efficiency yang diukur BOPO pada Sektor Perbankan Indonesia periode 2009-2013 memiliki persentase yang terlalu tinggi melebihi batas maksimum yang ditentukan BI. Hal tersebut mengindikasikan bahwa biaya operasional yang ditanggung bank terlalu tinggi karena kemampuan bank dalam mengelola kegiatan operasionalnya yang rendah, sehingga berpengaruh pada tingkat efisiensi perbankan dan kemampuan bank dalam menghasilkan keuntungan bersih (net income). Terbukti pada Sektor Perbankan Indonesia periode 2009-2013 kondisi net income mengalami kecenderungan penurunan bahkan bernilai negatif dan ketika bank mengalami net income yang negatif mengindikasikan bank mengalami kemungkinan ancaman financial distress. Oleh karena itu temuan teoritis pada penelitian ini sesuai dengan teori yang dikemukakan oleh (Kuncoro dan Suhardjono, 2002:569) dan (Frianto 2012:72).

\section{Pengaruh Earning terhadap Financial Distress Sektor Perbankan Indonesia}

Hasil penelitian empiris diperoleh keterangan bahwa earning yang diukur dengan ROA berpengaruh terhadap financial distress hal tersebut dibuktikan pada hasil statistik yang menyatakan estimasi regresi variabel earning yang diukur dengan ROA diperoleh nilai signifikansi dari thitung adalah 0,000 yang artinya nilai tersebut lebih kecil dari taraf nyata $5 \%$.

Kondisi earning yang diukur dengan ROA pada Sektor Perbankan Indonesia periode 2009-2013 memiliki presentase yang terlalu rendah dibawah batas minimum yang ditentukan BI. Hal tersebut mengindikasikan bahwa kemampuan bank yang masih rendah dalam pengelolaan aset produktif, hal ini tentu berpengaruh pada turunnya kontribusi pertumbuhan laba bagi perbankan. Terbukti kondisi net income pada Sektor Perbankan Indonesia periode 2009-2013 mengalami kecenderungan menurun dan bernilai negatif dan pada saat bank mengalami net income yang negatif kemungkinan bank mengalami ancaman financial distress akan terjadi. Oleh karena itu temuan teoritis pada penelitian ini sesuai dengan teori yang dikemukakan oleh (Veitzhal, et al, 2012:480) dan (Dendawijaya, 2009:120).

\section{Pengaruh Liquidity terhadap Financial Distress Sektor Perbankan Indonesia \\ Hasil penelitian empiris diperoleh} keterangan bahwa liquidity yang diukur dengan LDR tidak berpengaruh terhadap financial distress, hal tersebut dibuktikan pada hasil statistik yang menyatakan estimasi regresi variabel liquidity yang diukur dengan LDR diperoleh nilai signifikansi dari thitung adalah 0,102 yang artinya nilai tersebut lebih kecil dari taraf nyata $5 \%$.

Hal yang berbeda terjadi dalam penelitian ini yang menunjukkan bahwa nilai liquidity yang diukur dengan LDR pada Sektor Perbankan Indonesia periode 2009-2013 cenderung mengalami kenaikan. Hal tersebut mengindikasikan bahwa semakin tinggi LDR semakin tinggi pula penyaluran dana pihak ketiga kedalam bentuk kredit sehingga dengan tumbuhnya kredit mendorong pertumbuhan net income sebuah bank.

Hal ini terjadi karena besarnya LDR akan mempengaruhi tingkat profitabilitas bank dalam kesempatan mendapatkan bunga dan meningkatkan pendapatan bank, akan tetapi nilai LDR yang terlalu tinggi akan mengganggu tingkat likuiditas. Bank dapat mengurangi resiko likuiditas tersebut ketika aktiva bank yang diinvestasikan cukup likuid bilamana harus mencairkan aktiva tersebut untuk menutupi kebutuhan dana. Sehingga tingginya kredit yang disalurkan menggunakan dana pihak ketiga tidak akan mengganggu aktivitas operasional perusahaan sehingga bank masih dapat memiliki kemampuan menghasilkan keuntungan. Oleh karena itu temuan teoritis pada penelitian ini sesuai dengan teori yang dikemukakan oleh 
(Veithzal Rivai, Andria dan Ferry 2007:724) dan (Anam, 2013:3).

\section{KESIMPULAN DAN REKOMENDASI}

\section{Kesimpulan}

Berdasarkan uraian teori, hasil penelitian dan analisis baik secara deskriptif maupun verifikatif menggunakan analisis regresi multipel mengenai pengaruh CAMEL yang terdiri dari Capital, Management Efficiency, Earning dan Liquidity terhadap financial distress pada Sektor Perbankan Indonesia periode 20092013 dapat disimpulkan sebagai berikut.

1. Gambaran Capital yang diukur dengan Capital Adequacy Ratio (CAR) Sektor Perbankan Indonesia selama periode 20092013 cenderung mengalami kenaikan. Gambaran management efficiency yang diukur dengan Biaya Operasional terhadap Pendapatan Operasional (BOPO) Sektor Perbankan Indonesia selama periode 20092013 cenderung mengalami kenaikan.

2. Gambaran earning yang diukur dengan Return on Asset (ROA) Sektor Perbankan Indonesia selama periode 2009-2013 cenderung mengalami penurunan.

3. Gambaran liquidity yang diukur dengan Loan to Deposit Ratio (LDR) Sektor Perbankan Indonesia selama periode 20092013 cenderung mengalami kenaikan.

4. Gambaran financial distress yang diukur dengan Net Income Sektor Perbankan Indonesia selama periode 2009-2013 cenderung mengalami kenaikan.

5. Hasil penelitian pengaruh capital adequacy terhadap financial distress pada Sektor Perbankan Indonesia menunjukkan hasil tidak berpengaruh terhadap financial distress.

6. Hasil penelitian pengaruh management efficiency terhadap financial distress pada Sektor Perbankan Indonesia menunjukkan hasil berpengaruh terhadap financial distress.

7. Hasil penelitian pengaruh earning terhadap financial distress pada Sektor Perbankan Indonesia menunjukkan hasil berpengaruh terhadap financial distress.

8. Hasil penelitian pengaruh liquidity terhadap financial distress pada Sektor Perbankan Indonesia menunjukkan hasil tidak berpengaruh terhadap financial distress.

\section{Rekomendasi}

Berdasarkan kesimpulan, maka direkomendasikan hal-hal berikut:
1. Kondisi capital Sektor Perbankan Indonesia yang cenderung terus meningkat setiap tahunnya sehingga nilai capital yang diukur dengan CAR dapat dikatakan terlalu tinggi. Oleh karena itu sebaiknya bank dapat mengambil keputusan untuk dapat mengelola cadangan modalnya yang terlalu besar untuk dapat dialokasikan kedalam aktiva yang produktif sehingga dapat mendorong bank menghasilkan keuntungan yang lebih.

2. Kondisi management efficiency Sektor Perbankan yang cenderung meningkat setiap tahunnya sehingga nilai management efficiency yang diukur dengan BOPO dapat dikatakan terlalu tinggi. Oleh karena itu sebaiknya manajemen bank meningkatkan tingkat efisiensi khususnya dalam menjalankan kegiatan operasionalnya sehingga dapat memangkas biaya operasional yang terlalu tinggi dan menghasilkan pendapatan yang lebih tinggi.

3. Kondisi earning Sektor Perbankan yang cenderung menurun setiap tahunnya sehingga nilai earning yang diukur dengan ROA dapat dikatakan terlalu rendah. Oleh karena itu sebaiknya bank dapat mengambil keputusan untuk meningkatkan pengelolaan aktiva produktif yang dimiliki bank dengan efektif dan efisien.

4. Kondisi liquidity Sektor Perbankan yang cenderung meningkat setiap tahunnya sehingga nilai liquidity yang diukur dengan LDR dapat dikatakan terlalu tinggi. Oleh karena itu sebaiknya bank mempertimbangkan kembali ketika akan memberikan kredit hendaknya disalurkan dengan prinsip kehati-hatian (prudent) sehingga menghasilkan imbal hasil yang optimal dan bank tetap memiliki likuiditas yang tinggi.

5. Kondisi financial distress Sektor Perbankan yang cenderung meningkat setiap tahunnya terlihat pada kondisi net income sebagai indikator financial distress yang terus menurun. Oleh karena itu sebaiknya ketika bank mengalami financial distress hendaknya melakukan langkah-langkah antisipasi dan merancang berbagai strategi salah satunya dengan memperhatikan aspek CAMEL, sehingga semua unsur tersebut dapat dijadikan sebagai deteksi dini bank ketika sedang mengalami financial distress sehingga dapat terhindar dari ancaman kebangkrutan.

6. Peneliti merasa masih banyak keterbatasan dalam melakukan penelitian maka bagi para peneliti yang akan melakukan penelitian mengenai financial distress, sebaiknya menambah periode penelitian, menambah jumlah perusahaan serta mencari indikator 
lain yang bisa memprediksi financial distress.

\section{DAFTAR PUSTAKA}

Almilia, Luciana Spica \& Winny Herdiningtyas. 2005. Analisis Rasio CAMEL Terhadap Kondisi Bermasalah Pada Lembaga Perbankan Periode 20002002. Jurnal Akuntansi \& Keuangan, Vol. 7, No. 2, Hal. 131-147.

Anam, A. Khoirul. 2013. Risiko Likuiditas dan Dampaknya terhadap Kinerja Perbankan di Indonesia. Jurnal Dinamika Ekonomi. Vol. 10 No. 1 Maret 2013

Arwinda dan Lely. 2014. Pengaruh Mekanisme Corporate Governance, Likuiditas, Leverage dan Ukuran Perusahaan pada Financial Distress. E-Jurnal Akuntansi Universitas Udayana, Vol. 1, No. 1, Hal. 93-106.

Brigham, Eugene F \& Daves, Philip R. 2009. Intermediate Financial Management. USA: Thompson South Western.

CA. Ruchi Gupta. 2014. An Analysis of Indian Public Sector Banks Using CAMEL Approach. IOSR Journal of Business and Management Vol.16 No.1, Hal.94102.

David G Mayes \& Hanno Stremmel. 2014. The Effectiveness Of Capital Adequacy Measures In Predicting Bank Distress. SUERF - The European Money and Finance Forum Study 2014/1, ISBN: 978-3-902109-72-9.

Dendawijaya, Lukman. 2009. Manajemen Perbankan. Jakarta:Ghalia

Ferrouchi, El Mehdi. 2014. Moroccon Banks Analysis Using CAMEL Model. International Journal of Economics and Financial Issues, Vol. 4, No. 3, Hal. 622-627.

Frianto Pandia. 2012. Manajemen Dana dan Kesehatan Bank. Jakarta : Rineka Cipta.

John, Jens, dan Jan. 2010. Predicting Financial Distress and the Performance of Distressed Stocks. Journal of Investment Management Vol. 9, No. 2, Hal.14-34.

Kasmir. 2012. Manajemen Perbankan Edisi Revisi. Jakarta : PT RajaGrafino Persada

Koch, Timothy W dan Mac Donald, S. Scot. 2009. Bank Management, Fourth Edition. South Western: Cengange Learning.

Mishra dan Parvesh Kumar Aspal. 2013. A Camel Model Analysis of State Bank
Group. World Journal of Social Sciences. Vol. 3. No. 4. July 2013 Issue. Hal. 36 - 55

Kuncoro dan Suhardjono. 2002. Manajemen Perbankan Teori dan Aplikasi. Yogyakarta : BBPFE UGM

Olivier Brossard et al. 2007. An Early Warning Model for EU banks with Detection of the Adverse Selection Effect. Groupement de Rechercher Economiques et Sociales: http://www.gres-so.org

Pasaribu dan Rosa Luxita. 2011. Analisis Tingkat Kecukupan Modal dan Loan to Deposit Ratio Terhadap Profitabilitas. Jurnal Telaah dan Riset Akuntansi, Vol. 4, No.2, Hal. 144-125.

Platt, Harland D dan Marjorie B. Platt. 2006. Understanding Differences Between Financial Distress and Bankruptcy. Review of Applied Economics, Vol. 2, No. 2, Hal : 141-157.

Rahman, Rashidah Abdul dan Mazni. 2014. The Use Of “CAMELS" In Detecting Financial Distress Of Islamic Banks In Malaysia. The Journal of Applied Business Research. Vol. 30, No. 2, Hal. 445-452.

Ridwan Nurazi \& Michael Evans. 2005. An Indonesian Study of the Use of CAMEL(S) Ratios as Predictors of Bank Failure. Journal of Economic and Social Policy. Vol.10. No. 1 Juli 2005

Rose dan Hudgins. 2002. Bank Management \& Financial Services 8 Edition. New York : Mc Graw-Hill

Silvanita, Mangani. 2012. Bank dan Lembaga Keuangan Lain. Jakarta: Erlangga.

Veithzal Rivai, Andria Permata Veithzal dan Ferry N. Idroes. 2007. Bank and Financial Institution Mangement. Jakarta : PT. RajaGrafindo Persada.

Veitzhal, Sofyan, Sarwono dan Arifiandy. 2012. Commercial Bank Management Manajemen Perbankan Dari Teori ke Praktik. Jakarta: PT. RajaGrafindo Persada.

Whitaker, R.B. 1999. The Early Stages of Financial Distress. Journal of Economics and Finance, Vol. 23, No.2. Hal. 123-133 